\title{
Relationship between water, urine and serum fluoride and fluorosis in school children of Jhajjar District, Haryana, India
}

\author{
Sunil Kumar' ${ }^{1}$ Suman $\operatorname{Lata}^{2} \cdot{\text { Jyoti } \operatorname{Yadav}^{3} \cdot \text { J. P. Yadav }}^{2}$
}

Received: 20 March 2016/Accepted: 11 October 2016/Published online: 24 October 2016

(C) The Author(s) 2016. This article is published with open access at Springerlink.com

\begin{abstract}
The present study was undertaken to determine the relationship between fluoride in water, urine and serum and dental fluorosis. The fluoride level in water and urine were measured spectrophotometrically by using acid zirconyl and SPADNS reagents, while the fluoride level in serum was determined by ion selective electrode meter. Dental fluorosis survey was conducted with the help of Performa prescribed by Rajiv Gandhi Drinking Water Mission and the use of Tooth Surface Index for Fluorosis. Mean fluoride values in water samples of Jhajjar City and Dadanpur and Dariyapur villages of Jhajjar District were measured to be 2.17 (range from 1.92 to $2.60 \mathrm{mg} / \mathrm{L}$ ), 2.81 (range from 2.53 to $3.14 \mathrm{mg} / \mathrm{L}$ ) and $2.22 \mathrm{mg} / \mathrm{L}$ (range from 1.63 to $3.33 \mathrm{mg} / \mathrm{L}$ ), respectively. The mean fluoride values in the urine samples of children were found to be 1.51 (range from 0.05 to $2.64 \mathrm{mg} / \mathrm{L}$ ), 1.71 (range from 0.69 to $2.80 \mathrm{mg} / \mathrm{L}$ ) and $1.45 \mathrm{mg} / \mathrm{L}$ (range from 0.31 to $2.50 \mathrm{mg} / \mathrm{L}$ ) at Jhajjar City and Dadanpur and Dariyapur sites, respectively. Serum fluoride was detected in the blood samples of children, who have high urinary fluoride at these three sites. The mean serum fluoride level was reported to be $0.15,0.34$ and $0.17 \mathrm{mg} / \mathrm{L}$, respectively. A total of 842 children were also analyzed for dental fluorosis. The mean values of fluorosis-affected children in Jhajjar, Dadanpur and Dariyapur were 51.90, 94.63 and $36.84 \%$,
\end{abstract}

J. P. Yadav

yadav1964@rediffmail.com

1 Department of Environment Science, M. D. University, Rohtak, Haryana 124001, India

2 Department of Genetics, M. D. University, Rohtak, Haryana 124001, India

3 Department of Physiology, Pt. B.D.S. University of Health Sciences, Rohtak, Haryana 124001, India respectively. A significantly positive correlation between water, urine, serum fluoride concentration and fluorosis was seen.

Keywords Fluorosis - Jhajjar District - Serum fluoride Urinary fluoride - Water fluoride

\section{Introduction}

The problem of excessive fluoride in groundwater in India is common and was first reported by Short et al. (1937) from the state of Andhra Pradesh. At present, fluorosis is endemic in 21 states of India out of the 29, affecting more than 65 million people, including 6 million children (Jha et al. 2010; Verma et al. 2016; Rao et al. 2015). However, fluoride contamination of groundwater is a serious problem in several countries throughout the world (Kebede et al. 2016). Bhaumik and Mondal (2016) reported that the ingestion of excessive quantities of fluoride during preeruptive tooth formation results in chronic endemic fluorosis. Yadav and Lata (2002) have demonstrated that $10 \%$ of the children were affected by fluorosis even when the concentration of fluoride in the water supply was $1.0 \mathrm{mg} / \mathrm{L}$. Fluoride is excreted primarily via urine (IPCS 2002). Urinary fluoride is widely measured as an early indicator of fluoride poisoning among not only fluoride-exposed workers, but also inhabitants of fluoride-polluted areas (Zipkin et al. 1956). When the renal function deteriorates, the ability to excrete fluoride through kidney markedly decreases, possibly resulting in greater accumulation of fluoride in the body (Koichi et al. 1984; Ugran et al. 2016). Absorption and accumulation of fluoride in bones is influenced by a wide range of factors: endemic contamination, nutritional status, addition of fluoride to a public 
water supply, the consumption of bottled or carbonated water, age, and sex (Husdan et al. 1976). The estimation of fluoride in the plasma is a good index of fluoride status in the human system. Fluorides in human serum are found in two forms; ionic fluoride $\left(\mathrm{F}^{-}\right)$and nonionic fluoride (NF). The latter constitutes $80-90 \%$ of total fluoride. The results of many studies suggest that serum $\mathrm{F}^{-}$is directly correlated with water fluoride concentration ( $\mathrm{Li}$ and $\mathrm{Ke} 1990$; Ahemed et al. 2012; Arshad and Shanavas 2013).

Various studies from the state of Haryana have assessed the fluoride level in drinking water, urine and different food items (Yadav et al. 2006, 2007; Singh et al. 2007). Ingestion of excess fluoride, mainly through fluoride-contaminated drinking water, caused different types of fluorosis. It has become important to study the fluoride contents in the groundwater in the fluorosis-affected areas and assess its effect on human population, particularly children in rural areas, who are the most exposed to such contaminated water. In the present study, an attempt was made to understand the relationship between fluoride in groundwater, urine, serum and prevalence and severity of dental fluorosis.

\section{Materials and methods}

\section{Study area description}

The area of Jhajjar District is 1834 sq.km and geographically situated at $28^{\circ} 37^{\prime} \mathrm{N}$ latitude and $76^{\circ} 39^{\prime} \mathrm{E}$ longitude and $214 \mathrm{~m}$ above the mean sea level (Fig. 1). Jhajjar City, Dadanpur and Dariyapur villages were chosen for the present study because of the availability of water fluoride data and the high incidence of fluorosis among the locals. Residents of these sites use groundwater as the main source of drinking water. The groundwater sources include hand pumps, tube wells and open wells. The selected locations have more than $2.17 \mathrm{mg} / \mathrm{L}$ mean fluoride concentration, detected during a preliminary survey of the district (Yadav et al. 2008).

\section{Collection and fluoride determination in water samples}

Random water samples from various drinking water sources (hand pumps, tube wells and open wells) were collected in an ice box from each location. A total of ten samples were collected from each selected location, representing the water quality of the whole area. The samples were transported to the laboratory and analyzed. Fluoride concentration was determined spectrophotometrically using acid zirconyl and SPADNS reagents (Bellack and
Schouboe 1968). Sodium fluoride was used to prepare the standard solution.

\section{Collection and fluoride determination in urine samples}

To analyze the level of fluoride in urine, the spot urine samples of school-going children aged 8 and 15 years were collected. The urine composite samples of $24 \mathrm{~h}$ duration from 9 AM to 9 AM the next day were collected from each location. The urine samples were collected in non-reactive plastic containers and brought to the laboratory in an ice box and stored at $4{ }^{\circ} \mathrm{C}$ in a refrigerator. A total of 100 urine samples from each site were collected and analyzed for fluoride content using the SPADNS method.

\section{Collection and fluoride determination in serum samples}

To analyze the level of fluoride in serum, blood samples ( $5 \mathrm{ml}$ ) of 66 children (22 from each location) were drawn intravenously using sterilized needle and syringe and transferred to a dried glass vial at room temperature. After $20 \mathrm{~min}$, the blood was centrifuged at $2000 \mathrm{rpm}$ for $10 \mathrm{~min}$ at $4{ }^{\circ} \mathrm{C}$ and the supernatant (serum) collected and stored at $-20{ }^{\circ} \mathrm{C}$ until use. The fluorides in these samples were determined by Orion fluoride ion-specific electrode at IITR, Lucknow.

\section{Survey on dental fluorosis}

The fluorosis data were taken from the school-going children who were residing by birth in the villages to investigate the impact of groundwater fluoride on dental health. A questionnaire, completed with the assistance of the parents, was used to collect information on the personal characteristics (family socioeconomic status and lifestyle), exposure history to fluoride, medical history, etc. pro forma prescribed by Rajiv Gandhi Drinking Water Mission (1993) and earlier described by Dahyia et al. (2000) was used to score the incidence and degree of manifestation of dental fluorosis. The prescribed Tooth Surface Index of Fluorosis (TSIF) was also used, following Jackson et al.'s (1999) method to determine the prevalence of dental fluorosis.

\section{Statistical analysis}

The data were statistically analyzed using the SPSS statistical version 16.0 software. For each set of observations, mean, standard deviation and standard error were calculated. 


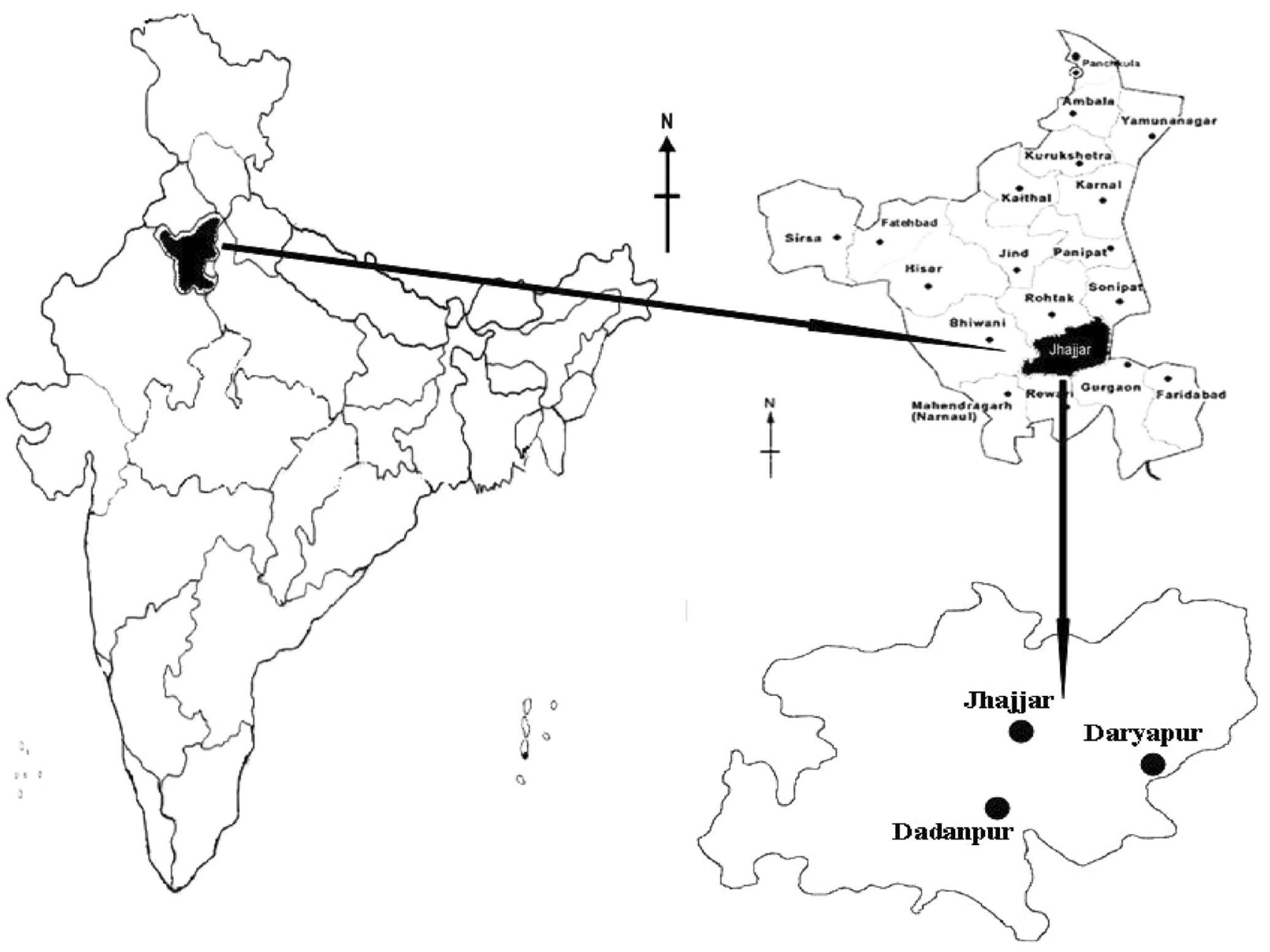

Fig. 1 Map showing the location of the study area

\section{Results}

\section{Fluoride concentration in groundwater, urine and serum}

The data of fluoride in drinking groundwater, urine samples and serum samples along with dental fluorosis has been given in Table 1. The mean fluoride level in Jhajjar was $2.17 \mathrm{mg} / \mathrm{L}$. The range of fluoride was $1.92-2.60 \mathrm{mg} / \mathrm{L}$. Dadanpur village has the highest mean fluoride value of $2.81 \mathrm{mg} / \mathrm{L}$ with a minimum and maximum level of 2.53 and $3.14 \mathrm{mg} / \mathrm{L}$, respectively. The mean fluoride level in Dariyapur village was $2.22 \mathrm{mg} / \mathrm{L}$ with a minimum of $1.63 \mathrm{mg} / \mathrm{L}$ and maximum level of $3.33 \mathrm{mg} / \mathrm{L}$. It was observed that $100 \%$ samples of drinking groundwater collected from the three locations exceeded the maximum desirable limit of $1 \mathrm{mg} / \mathrm{L}$ as laid down by the Bureau of Indian Standard (BIS 1991). The mean fluoride level in the urine samples of individuals of Jhajjar, Dadanpur and Dariyapur was $1.51,1.71$ and $1.45 \mathrm{mg} / \mathrm{L}$, respectively.
Similarly, the mean fluoride level in serum samples was $0.15 \mathrm{mg} / \mathrm{L}$ in Jhajjar, $0.34 \mathrm{mg} / \mathrm{L}$ in Dadanpur and $0.17 \mathrm{mg} /$ $\mathrm{L}$ in Dariyapur. A significant positive correlation was found between the fluoride content in drinking groundwater and urine $(r=0.997)$, drinking groundwater and serum $(r=0.994)$, and serum and urine (0.949) (Table 2).

\section{Prevalence of dental fluorosis in young children}

To analyze the levels of fluorosis, 842 children were examined. $51.90 \%$ children of Jhajjar, $94.63 \%$ of Dadanpur and $36.84 \%$ of Dariyapur village were found to be affected with fluorosis. The stages of dental fluorosis among the individuals were chalky white, yellowish brown and brownish black with horizontal streaks, spots and both spots and streaks. The percentage distribution of dental fluorosis according to TSIF score among affected children is given in Tables 3 and 4. Any examined permanent tooth surface having a TSIF score 0 was defined as not affected with fluorosis. TSIF 1 was defined as fluorosis affected to 
Table 1 Data on fluoride level in water, urine, serum and percentage of fluorosis-affected children

\begin{tabular}{lllll}
\hline Sites & Fluoride in water $(\mathrm{mg} / \mathrm{L})$ & Fluoride in urine samples $(\mathrm{mg} / \mathrm{L})$ & Fluoride in serum $(\mathrm{mg} / \mathrm{L})$ & \%Age of fluorosis-affected children \\
\hline Jhajjar & $2.17 \pm 0.09^{\mathrm{a}}$ & $1.51 \pm 0.13$ & $0.15 \pm 0.01$ & $232 / 447=51.90$ \\
& $0.30^{\mathrm{b}}$ & 0.62 & 0.04 & \\
& $1.92-2.60^{\mathrm{c}}$ & $0.05-2.64$ & $0.07-0.27$ & $194 / 205=94.63$ \\
Dadanpur & $2.81 \pm 0.08$ & $1.71 \pm 0.13$ & $0.34 \pm 0.04$ & $70 / 190=36.84$ \\
& 0.26 & 0.60 & 0.21 & \\
& $2.53-3.14$ & $0.69-2.80$ & $0.18-1.05$ & \\
Dariyapur & $2.22 \pm 0.20$ & $1.45 \pm 0.15$ & 0.18 & 0.04 \\
& 0.65 & 0.72 & $0.07-0.46$ &
\end{tabular}

a represents mean \pm standard error,

b represents standard deviation and

c represents minimum and maximum value

Table 2 The correlation of water, urine, serum fluoride and dental fluorosis

\begin{tabular}{lc}
\hline Parameters & $r$ values \\
\hline Water and urine & $0.997^{*}$ \\
Water and serum & $0.994^{*}$ \\
Urine and serum & $0.949^{*}$ \\
Water and dental fluorosis & $0.952^{*}$
\end{tabular}

* Significant at the $5 \%$ level

some extent. As the TSIF score increased (2-7), the severity of fluorosis among children also increased. TSIF score 4 was most prevalent (Table 4) and was found at all the places. Children with TSIF score 4 showed staining of tooth enamel that may range from light to very dark brown.

\section{Discussion}

\section{Occurrence of fluoride in groundwater}

Fluoride concentration higher than $1.5 \mathrm{mg} / \mathrm{L}$ in drinking water, as prescribed by the WHO, results in dental and skeletal fluorosis, and renal and neuronal disorders along with myopathy (Ayoob and Gupta 2006; Das and Nag 2016; Narsimha and Sudarshan 2016). In the present study,

Table 3 Data on the incidence and severity of dental fluorosis in school children

\begin{tabular}{|c|c|c|c|c|c|c|c|c|}
\hline \multirow[t]{2}{*}{ Sites } & \multirow{2}{*}{$\begin{array}{l}\text { No. of individuals } \\
\text { examined }\end{array}$} & \multirow{2}{*}{$\begin{array}{l}\text { No. of affected } \\
\text { individuals }\end{array}$} & \multicolumn{3}{|c|}{ Stages of dental fluorosis } & \multicolumn{3}{|c|}{ Types of dental fluorosis } \\
\hline & & & $\begin{array}{l}\text { Chalky } \\
\text { white }\end{array}$ & $\begin{array}{l}\text { Yellowish } \\
\text { brown }\end{array}$ & $\begin{array}{l}\text { Brownish } \\
\text { black }\end{array}$ & $\begin{array}{l}\text { Horizontal } \\
\text { streaks }\end{array}$ & Spots & Both \\
\hline Jhajjar & 447 & $232(51.90)$ & $\begin{array}{l}110 \\
\quad(24.61)\end{array}$ & $98(21.93)$ & $24(5.37)$ & $90(20.13)$ & $\begin{array}{l}121 \\
(27.07)\end{array}$ & $21(4.70)$ \\
\hline Dadanpur & 205 & $194(94.63)$ & $73(35.61)$ & $101(49.27)$ & $20(9.75)$ & $75(36.58)$ & $\begin{array}{l}48 \\
\quad(23.41)\end{array}$ & $\begin{array}{l}71 \\
\quad(34.63)\end{array}$ \\
\hline Dariyapur & 190 & $70(36.84)$ & $12(6.31)$ & $45(23.68)$ & $13(6.84)$ & $21(11.05)$ & $\begin{array}{l}40 \\
\quad(21.05)\end{array}$ & $9(4.74)$ \\
\hline
\end{tabular}

Figures in parenthesis represent the percentage

Table 4 Percent distribution of fluorosis in children by TSIF (number of individuals in parenthesis)

\begin{tabular}{|c|c|c|c|c|c|c|c|}
\hline \multirow[t]{2}{*}{ Sites } & \multicolumn{7}{|c|}{ TSIF score } \\
\hline & $\mathrm{N}$ & 0 & 1 & 2 & 3 & 4 & $5-7$ \\
\hline Jhajjar & 447 & $48.10(215)$ & $4.47(20)$ & $8.95(40)$ & $11.18(50)$ & $21.93(98)$ & $5.37(24)$ \\
\hline Dadanpur & 205 & $5.36(11)$ & $9.76(20)$ & $12.19(25)$ & $13.11(27)$ & 49.27 (101) & $10.31(21)$ \\
\hline Dariyapur & 190 & $63.16(120)$ & $0(0)$ & $0(0)$ & $6.31(12)$ & $23.68(45)$ & $6.84(13)$ \\
\hline
\end{tabular}

Number given in parenthesis represents the number of individuals 
geological sources and fertilizer used in agriculture are the possible contributors of fluoride in groundwater, and industrial input is absent due to the rural setting. The study area consists of alluvial plains with sand, silt and clay and kankar mixed in different proportions. Jhajjar District is a part of the Dugan ethnic plain ranging from Pleistocene to recent in age, and Aeolian deposits of sub-recent age cap the plains. The soil texture comprises loam, yellowish and brown in color. The geological formation of Gurgaon District, which is the adjacent district to the study area, has been described by Singh (1996). He demonstrated that the Aravalli system is the oldest formation available in Gurgaon District and composed of quartzite sandstone, mica schists, phyllites, silica sand, china clay, ordinary sand, crystalline limestone, etc. The population of the study area depends on the groundwater for drinking purpose. The mean values of fluoride levels at all the three locations were found to be more than the prescribed value of $1 \mathrm{ppm}$ (WHO 1996).

Drinking water consumption by the human body totally depends on the atmospheric temperature. Extremely hot conditions were present in the study area during the summer season and the temperature ranged from 25 to $48{ }^{\circ} \mathrm{C}$. The optimal concentration of fluoride in drinking water for regions with extreme climates should be $0.5-0.7 \mathrm{mg} / \mathrm{L}$, as prescribed by World Health Organization (Murray 1986). A study conducted by Singh et al. (2007) in Gurgaon District, adjacent to the study area, revealed that the water consumption was approximately $2.5 \mathrm{~L}$ per child per day during the months of April to August. They observed that the fluoride intake by children from ingested water was 4.20, 4.45 and $8.05 \mathrm{mg}$ fluoride/ person/day at Pataudi, Harsaru and Haily Mandi villages, respectively, whereas in the present study fluoride intake by children from ingested water was 5.44, 7.05 and $5.57 \mathrm{mg}$ fluoride/person/day at Jhajjar, Dadanpur and Dariyapur villages, respectively with $2.5 \mathrm{~L}$ drinking water consumption per child per day. The results of fluoride ingestion are closely related in both the studies. Yadav et al. (2007) suggested that absorption of fluoride from water ranges from 86 to $97 \%$. The Central Ground Water Board (2007) also reported a higher groundwater fluoride level in Jhajjar District ranging from 1.73 to $5.94 \mathrm{mg} / \mathrm{L}$ and recommended that groundwater consumption was harmful for humans. The highest groundwater fluoride concentration from Haryana State was $48 \mathrm{mg} / \mathrm{L}$ in Rewari District (UNICEF 1999), adjacent district to the study area. The dietary fluoride intake recommended by the National Research Council (1989) is in the range of 0.1-1.0 $\mathrm{mg} /$ person/day for children under the age of 1 year; 0.5 to $1.5 \mathrm{mg} /$ person/day for children between 1 and 3 years; up to $2.5 \mathrm{mg} /$ person/day for children under 12 years and $1.5-4.0 \mathrm{mg} /$ person/day for adults. During the study, only drinking water-ingested fluoride was calculated, which was higher than the recommended dietary fluoride limit for adults. It is evident from the results that the population in the study area is chronically exposed to higher levels of fluoride from drinking water. Various studies from different parts of the world showed the excess of fluoride in groundwater: Sri Lanka (Dissanayake 1991), Serbia (Mandinic et al. 2010), China (Chen et al. 2012), Ethiopia and Malawi (Msonda et al. 2007). Excessive groundwater fluoride level was also reported in several states of India: Rajasthan (Choubisa 1997), Tamil Nadu (Gopalakrishnan et al. 1991), Uttar Pradesh (Jha et al. 2010), Bihar (Verma et al. 2016), Chhattisgarh (Patel et al. 2015) and Haryana (Singh et al. 2007; Meenakshi et al.2004; Yadav and Lata 2003).

\section{Relationship between dental fluorosis, urine and serum fluoride}

Three sites were screened to conduct the survey on the prevalence of dental fluorosis based on the higher fluoride concentration in groundwater. Nearly $50 \%$ of the absorbed fluoride in each day becomes associated with calcified tissues within $24 \mathrm{~h}$ and the remainder is excreted in the urine (Neuman and Neuman 1958). In plasma, fluoride is transported as ionic fluoride and non-ionic fluoride. Ionic fluoride does not bind to plasma proteins and is easily excreted with the urine (Singh et al. 2007). Urinary fluoride clearance increases with urine $\mathrm{pH}$ due to a decrease in the concentration of HF (IPCS 2002). Other studies have also shown that the uptake of fluoride by the skeleton is most efficient in children and decreases with age (Whitford 1999; Ozsvath 2009; Viswanathan et al. 2009). The present study revealed that the prevalence of dental fluorosis increases with increase of groundwater fluoride concentration. In Dadanpur village $94.63 \%$ surveyed children were affected by dental fluorosis, out of which $49.27 \%$ were suffering from yellowish brown stage of dental fluorosis and $36.58 \%$ from horizontal streak type of dental fluorosis. Statically positive significant correlation $(r=0.952)$ occurs between groundwater fluoride and dental fluorosis. Other studies also showed that dental fluorosis increases with fluoride concentration in drinking water (Viswanathan et al. 2009; Mandinic et al. 2010; Rango et al. 2012). The fluoride level in biomaterials such as urine and blood has been proposed as the most reliable indicator of exposure to fluoride (Kokot and Drzewiecki 2000). The generally accepted fluoride concentration in serum is $0.15 \mathrm{ppm}$ (Singer and Armstrong, 1965). The acceptable concentration of urine fluoride is $1 \mathrm{mg} / \mathrm{L}$ (Jaganmohan et al. 2010). The mean serum fluoride levels were higher than the accepted values at two locations (Dadanpur and Dariyapur). However, the mean serum 
Table 5 Literature data on serum, urine and water fluoride concentration

\begin{tabular}{lllll}
\hline & Serum F $\mu \mathrm{g} / \mathrm{L}$ & Urinary F $\mu \mathrm{g} / \mathrm{L}$ & Water F $\mu \mathrm{g} / \mathrm{L}$ & Locations \\
\hline Husdan et al. $(n=136)$ & $9.5-43.7$ & No results & No results & Toronto \\
Parkins et al. $(n=41)$ (optimal fluoridated water) & $19-112$ & No results & No results & Iowa City \\
Shimonovitz et al. $(n=20)$ & $30.3 \pm 15$ & No results & $0.22-0.49$ & Jerusalem \\
Abdennebi et al. & No results & $170-47,500$ & 1003 & Youssoufia city \\
Torra et al. $(n=250)$ & $1-45$ & $159-1990$ & 200 & Barcelona \\
Singh et al. $(n=400)$ & No results & $900-3250$ & $950-5200$ & Gurgaon \\
Jaganmohan et al. $(n=90)$ & $1470-2270$ & $1070-4000$ & $2370-6740$ & Nellore \\
Present study & $70-1050(n=66)$ & $50-2800(n=100)$ & $2400(n=30)$ & Jhajjar \\
\hline
\end{tabular}

fluoride value at Jhajjar ranged from 0.07 to $0.27 \mathrm{mg} / \mathrm{L}$ with a mean value of $0.15 \mathrm{mg} / \mathrm{L}$. Fluoride in urine samples from the study area sites was higher than the prescribed accepted level of $1 \mathrm{mg} / \mathrm{L}$. Elevated concentration in urine supported a clinical diagnosis of fluorosis (Nayak et al. 2009).

The significant positive correlation between the fluoride contents of drinking groundwater, urine, serum and prevalence of dental fluorosis among the sampled children is consistent with the findings of Xiang et al. (2004) and suggest that fluorosis among the investigated village children population is mainly caused by fluoride in drinking groundwater. As these children were residing at these places since birth, they were exposed to fluoride in drinking groundwater from the time of permanent teeth formation and enamel maturation, reflecting dental fluorosis.

The various studies on fluoride level (Parkins et al. 1974; Husdan et al. 1976; Shimonovitz et al. 1995; Abdennebi et al. 1995; Torra et al. 1998; Singh et al. 2007; Jaganmohan et al. 2010) in groundwater, serum and urine have been shown in Table 5. The present investigation indicates that fluoride concentrations in serum were higher than those in earlier studies, except fluoride reported by Jaganmohan et al. (2010). Similarly, urinary fluoride concentration was also higher, except fluoride reported by Abdennebi et al. (1995); Singh et al. (2007) and Jaganmohan et al. (2010).

\section{Conclusion}

Fluoride when taken in controlled quantities reduces tooth decay. But excess fluoride ingested through all sources adversely affects the appearance of children's teeth during development and causes dental fluorosis. The ingested fluoride level in children in the study area was higher than the recommended dietary fluoride limit for children given by the National Research Council. The present study revealed that the underground drinking water of the investigated region was contaminated with fluoride, and the population of the study area was chronically exposed to higher levels of fluoride from drinking water. There was a significantly positive correlation between the fluoride content of groundwater, urine and serum of fluorosis-affected children. This suggests that a high level of fluorosis in the study area was due to the consequence of a higher concentration of fluoride in underground aquifers. A maximum number of fluorosis-affected children $(94.63 \%)$ were recorded from Dadanpur village. The study also revealed that the fluoride level in urine and serum was also higher than the accepted level. Thus, there is a need to be aware of the removal of excess fluoride from drinking water.

Open Access This article is distributed under the terms of the Creative Commons Attribution 4.0 International License (http:// creativecommons.org/licenses/by/4.0/), which permits unrestricted use, distribution, and reproduction in any medium, provided you give appropriate credit to the original author(s) and the source, provide a link to the Creative Commons license, and indicate if changes were made.

\section{References}

Abdennebi EH, Fandi R, Lamnaouer D (1995) Human fluorosis in Morocco: analytical and clinical investigations. Veterin Human Toxico 37:465-468

Ahemed I, Rafique T, Hasan SK, Khan N, Khan MH, Usmani TH (2012) Correlation of fluoride in drinking water with urine, blood plasma and serum fluoride levels of people consuming high and low fluoride drinking water in Pakistan. Fluoride 45(4):384-388

Arshad M, Shanavas P (2013) Comparison of serum and urinary fluoride levels among fertilizer and wood industry worker in Mangalore city, India. Fluoride 46(2):80-82

Ayoob S, Gupta AK (2006) Fluoride in drinking water: a review on the status and stress effects. Critical Rev Environ Sci Technol 36:433-487

Bellack E, Schouboe PJ (1968) Rapid photometric determination of fluoride with SPADNS-Zirconium lake. Anal Chem 30:2032-2035

Bhaumik R, Mondal NK (2016) Optimizing adsorption of fluoride from water by modified banana peel dust using response surface modeling approach. Appl Water Sci 6:115-135

Bureau of Indian Standards (BIS) (1991) Indian Standard Specification for drinking water, IS:10500. New Delhi 
Central Ground Water Board (CGWB) (2007) Ground water information booklet, Jhajjar district, Haryana

Chen H, Yan M, Yang X, Chen Z, Wang G, Schmidt-Vogt D, Xu Y, $\mathrm{Xu} J$ (2012) Spatial distribution and temporal variation of high fluoride contents in groundwater and prevalence of fluorosis in humans in Yuanmou County, Southwest China. J Hazard Mater 235-236:201-209

Choubisa SL (1997) Fluoride distribution and fluorosis in some villages of Banswara district of Rajasthan. Indian J Environ Hlth 39:281-288

Dahyia S, Kaur A, Jain N (2000) Prevalence of fluorosis among school children in rural area, district Bhiwani-a case study. Indian J Environ Health 42:192-195

Das S, Nag SK (2016) Geochemical appraisal of fluoride-laden groundwater in Suri I and II blocks, Birbhum district, West Bengal. Appl Water Sci. doi:10.1007/s1320-016-0452-x

Dissanayake CB (1991) The fluoride problem in the groundwater of Sri Lanka-environmental management and health. Internat J Environ Health Stud 38:137-156

Gopalakrishnan S, Narasimhan S, Seenipandian C (1991) Incidence of fluorosis in 10 villages near Tuticorin-Suggestions for prevention and control. Indian J Environ Prot 11:118-123

Husdan H, Vogl R, Oreopoulos D, Gryfe C, Rapoport A (1976) Serum ionic fluoride: normal range and relationship to age and sex. Clinical Chem 22:1884-1888

IPCS (2002) Fluorides. Environmental Health Criteria 227. World Health Organization, Geneva

Jackson RD, Sue AK, Kartz B, Brizendine E, Stooky GK (1999) Dental fluorosis in children residing in communities with different water fluoride level: 33-month follow-up. Pediatr Dent 21:248-254

Jaganmohan P, Narayana SVL, Sambasiva R (2010) Prevalence of high fluoride concentration in drinking water in Nellore district, Anadra Pradesh, India: a biochemical study to develop the relation to the rental failures. World J Med Sci 5:45-48

Jha SK, Nayak AK, Sharma VK (2010) Potential fluoride contamination in the drinking water of Marks Nagar, Unnao district, Uttar Pradesh, India. Enviorn Geochem Health 32:217-226

Kebede B, Beyene A, Fufa F, Megersa M, Behm M (2016) Experimental evaluation of sorptive removal of fluoride from drinking water using iron ore. Appl Water Sci 6:57-65

Koichi K, Yasuhisa Y, Misuzu W, Yoshihisa T, Toshiyuki H (1984) Urinary fluoride excretion in fluoride exposed workers with diminished renal function. Indust Health 22:33-40

Kokot Z, Drzewiecki D (2000) Fluoride levels in hair of exposed and unexposed populations in Poland. Fluoride 33:196-204

Li C, Ke X (1990) Ionic, Non-ionic and total fluoride in human serum. Fluoride 23:164-169

Mandinic Z, Curcic M, Antonijevic B, Carevic M, Mandic J, DjukicCosic D, Lekic CP (2010) Fluoride in drinking water and dental fluorosis. Sci Total Environ 408:3507-3512

Meenakshi Garg VK, Kavita Renuka, Malik A (2004) Groundwater quality in some villages of Haryana, India: focus on fluoride and fluorosis. J Hazard Mater 106B:85-97

Msonda KWM, Masamba WRL, Fabiano E (2007) A study of fluoride groundwater occurrence in Nathenje, Lilongwe, Malawi. Phys Chem Earth 32:1178-1184

Murray J (1986) Appropriate use of fluoride for human health. World Health Organization, Ginebra, p 3

Narsimha A, Sudarshan V (2016) Contamination of fluoride in groundwater and its effect on human health: a case study in hard rock aquifers of Siddipet, Telangana State, India. Appl Water Sci. doi:10.1007/s13201-016-0441-0

National Research Council (NRC) (1989) Recommended Dietary Allowances, 10th ed., NRC (National Research Council), p. 239
Nayak B, Roy MM, Das B, Pal A, Sengupta MK, De SP (2009) Health hazards of ground water fluoride contamination. Clin Toxicol 47:292-295

Neuman WF, Neuman MW (1958) The chemical dynamics of bone mineral. University of Chicago press, Chicago, pp 75-100

Ozsvath DL (2009) Fluoride and environmental health: a review. Environ Sci Biotechnol 8:59-79

Parkins FM, Tinanoff N, Mutinho M (1974) Relationships of human plasma fluoride and bone fluoride to age. Calciferous Tissue Res 16:335-338

Patel KS, Sahu BL, Dahariya NS, Bhatia A, Patel RK, Matini L, Sracek O, Bhattacharya P (2015) Groundwater arsenic and fluoride in Rajnandgaon District, Chhattisgarh, northeastern India. Appl Water Sci. doi:10.1007/s13201-015-0355-2

Rajiv Gandhi National Drinking Water Mission (1993) Prevention and control of fluorosis in India. Ministry of Rural Development, Govt. of India, New Delhi

Rango T, Kravchenko J, Atlaw B, McCornick PG, Jeuland M, Merola B, Vengosh A (2012) Groundwater quality and its health impact: an assessment of dental fluorosis in rural inhabitants of the Main Ethiopian Rift. Environ Internat 43:37-47

Rao NS, Rao PS, Dinakar A, Rao N, Marghade D (2015) Fluoride occurrence in the groundwater in a coastal region of Andhra Pradesh, India. Appl Water Sci. doi:10.1007/s13201-015-0338-3

Shimonovitz S, Patz D, Ever-Hadani P, Singer L, Zacut D, Kidroni G, Ron M (1995) Umbilical cord fluoride serum levels may not reflect a fetal fluoride status. J Perinatal Med 23:279-282

Short HE, McRobert TW, Bernard AS, Mannadinayer AS (1937) Endemic fluorosis in Madras presidency. Indian $\mathrm{J}$ Med Res 25:553-561

Singer L, Armstrong WD (1965) Determination of fluoride. Procedure based upon diffusion of hydrogen fluoride. Anal Biochem 10:495

Singh A (1996) Study of Subsurface Isotherm, Sohna Hot-Spring Area, Gurgaon district, Haryana, Geothermal Energy in India, Geological Survey of India Special Publication No. 45

Singh B, Gaur S, Garg VK (2007) Fluoride in drinking water and human urine in Southern Haryana, India. J Hazard Mater 144:147-151

Torra M, Rodamilans M, Corbella J (1998) Serum and urine ionic fluoride. Biol Trace Elem Res 63:67-72

Ugran V, Desai NN, Chakraborti D, Masali A, Mantur P, Kulkarni S, Deshmukh N, Chadchan KS, Das SN, Tanksali AS, Arwikar AS, Guggarigoudar SP, Vallabha T, Patil SS, Das KK (2016) Groundwater fluoride contamination and its possible health implication in Indi taluk of Vijayapura District (Karnataka State), India. Environ Geochem Health. doi:10.1007/s10653-016-9869-2

UNICEF (1999) State of the art report on the extent of fluoride in drinking water and the resulting endemicity in India. Report by Fluorosis Research \& Rural Development Foundation for UNICEF, New Delhi

Verma DK, Bhunia GS, Shit PK, Kumar S, Mandal J, Padbhushan R (2016) Spacial variability of groundwater quality of Sabour block, Bhagalpur district (Bihar, India). Appl Water Sci. doi:10. 1007/s13201-016-0380-9

Viswanathan G, Jaswanth A, Gopalakrishnan S, Siva Ilango S, Aditya G (2009) Determining the optimal fluoride concentration in drinking water for fluoride endemic regions in South India. Sci Total Environ 407:5298-5307

Whitford GM (1999) Fluoride metabolism and excretion in children. J Pub Health Dent 59:224-228

WHO (1996) Guidelines for Drinking-water Quality. Volume 2. Health Criteria and Other Supporting Information. 2nd edition, World Health Organization, Geneva

Xiang QY, Liang YX, Chen BH, Wang CS, Zhen SQ, Chen XD, Chen LS (2004) Serum fluoride and dental fluorosis in two villages in China. Fluoride 37:28-37 
Yadav JP, Lata S (2002) Assessment of fluoride toxicity and dental fluorosis in Sahlawas block of district Jhajjar, Haryana. J Foren Medic Toxicol 19:7-12

Yadav JP, Lata S (2003) Urinary fluoride levels and prevalence of dental fluorosis in children of Jhajjar District, Haryana. Indian J Med Sci 57:394-399

Yadav AK, Kaushik CP, Haritash AK, Kansal A, Rani N (2006) Defluoridation of groundwater using brick powder as an adsorbent. J Hazard Mat 128(2-3):289-293

Yadav AK, Kaushik CP, Haritash AK, Singh B, Raghuvanshi SP, Kansal A (2007) Determination of exposure and probable ingestion of fluoride through Tea, Toothpaste, Tobacco and Pan Masala. J Hazard Mater 142:77-80

Yadav JP, Lata S, Kumar S (2008) Fluoride distribution in underground drinking water sources of Jhajjar district, Haryana, India. Environ Geochem Health 31:431-438

Zipkin I, Likins RC, McClure FJ, Steere AC (1956) Urinary fluoride levels associated with use of fluoridated waters. Public Health Report 71:767 